\title{
The role of gamma interferon in infection of susceptible mice with murine coronavirus, MHV-JHM
}

\author{
Abigail L. Smith ${ }^{1,2}$, S. W. Barthold ${ }^{1}$, M. S. de Souza ${ }^{1,2}$, and Kim Bottomly ${ }^{3}$ \\ ${ }^{1}$ Section of Comparative Medicine, ${ }^{2}$ Department of Epidemiology and Public Health, and \\ ${ }^{3}$ Howard Hughes Medical Institute and Section of Immunobiology, \\ Yale University School of Medicine, New Haven, Connecticut, U.S.A.
}

Accepted March 31, 1991

Summary. Infection of BALB/c mice with mouse hepatitis virus, strain JHM (MHV-JHM), at any of several intervals relative to ovalbumin (OVA) administration resulted in elevated OVA-specific IgG 2 a titers. Since gamma interferon (IFN) has been implicated as an up-regulator of $\operatorname{IgG} 2$ a production, attempts were made to determine whether levels of this cytokine were modified in sera of infected mice. Serum IFN- $\gamma$ was not detected, but treatment of MHV-JHMinfected mice with monoclonal anti-IFN- $\gamma$ antibody resulted in high mortality with decreased survival times, enhanced virus titers in liver and spleen, and more severe virus-associated pathology, compared to mock-treated, infected mice. Immunotherapy with recombinant IFN- $\gamma$ ameliorated disease as reflected by mortality rates and virus titers in target organs.

\section{Introduction}

Mice inoculated with soluble protein antigens preferentially produce IgG 1 and IgG 3 specific to that antigen $[3,7]$. In contrast, infection of mice with any of several viruses enhances the IgG 2 a response both to the infecting virus and to immunizing soluble protein antigens [6-8]. Gamma interferon (IFN), a cytokine preferentially produced by the $\mathrm{T}_{\mathrm{h}} 1$ subset of $\mathrm{CD} 4^{+} \mathrm{T}$ cells [5], stimulates production of $\operatorname{IgG} 2$ a by $B$ lymphocytes activated in vitro and in vivo and inhibits $\operatorname{IgG} 1$ secretion $[12,30,31]$. Thus, it has been postulated that the immune response triggered by viruses mainly activates the $T_{h} 1$ subset of helper T cells [7].

Mouse hepatitis virus (MHV) is a singular name for a group of coronaviruses, family Coronaviridae, infecting laboratory mice worldwide at high prevalence $[18,20,22]$. Mice infected with MHV can exhibit aberrant immune responses that interfere with their usefulness in biomedical research $[4,9,10,27-29]$. 
Coutelier and co-workers [7] showed altered protein-specific isotype responses of mice infected with the A 59 strain of MHV one day prior to antigen administration. The initial goal of the currently reported experiments was to determine whether MHV-JHM infection yielded similar results and whether timing of virus exposure was critical to observing the effect, as has been reported for other experimental systems altered by MHV infection [4, 33]. MHV-JHM infection of the BALB/c mouse was exploited as representative of a combination of moderately virulent, pantropic virus in a commonly used permissive genotype. Based on the observation of elevated ovalbumin (OVA)-specific IgG 2 a levels in sera of mice infected with MHV-JHM at any of several intervals relative to antigen exposure, attempts were made to detect IFN- $\gamma$ in sera of infected mice and to reverse the $\operatorname{IgG} 2$ a elevation by administration of IFN- $\gamma$-specific antibody. The effect of this antibody and of immunotherapy with exogenous recombinant IFN- $\gamma$ on virus-associated mortality and pathology and on virus replication in target organs was examined.

\section{Materials and methods}

\section{Mice}

Female BALB/cByJ mice (The Jackson Laboratory, Bar Harbor, ME) were five to seven weeks old at the time of virus exposure. Young adult BALB/c nu/nu (athymic) and $\mathrm{nu} /+$ (euthymic) mice were obtained from Life Sciences, Inc. (St. Petersburg, FL). Cr; ORL Sencar dams with litters were obtained from the Animal Genetics and Production Branch, NCI (Bethesda, MD). Randomly selected mice were free of antibody to common murine viruses on arrival. All mice were housed in micro-isolator cages (Lab Products, Maywood, $\mathrm{NJ}$ ) and were given food and water ad libitum. Manipulations and husbandry were performed in a class II biological safety cabinet, and infected mice were housed in a facility separate from that used for control (uninfected) mice. An open-cage sentinel mouse seromonitoring program was in place during the course of the reported studies. Seroconversion to none of 11 common murine viruses or Mycoplasma pulmonis was detected, except among MHV-inoculated, immunocompetent mice which seroconverted to the infecting virus.

Virus

MHV-JHM (American Type Culture Collection, Rockville, MD) was used in the form of an infected infant mouse brain homogenate. Mice immunized with OVA or given antibody to IFN- $\gamma$ were exposed orally to $10^{4}$ infant mouse icLD 50 of virus. Mice treated with recombinant IFN- $\gamma$ were exposed intranasally to the same dose of virus. Intranasal exposure of $\mathrm{BALB} / \mathrm{c}$ mice generally results in nearly $100 \%$ mortality, whereas mortality rates after oral inoculation are less than $50 \%$ (unpubl. obs.).

\section{Ovalbumin (OVA) immunization}

Groups of mice were infected per os with MHV-JHM on days $-7,-4,-1,0,+1$, or +3 relative to intraperitoneal immunization with OVA ( $500 \mu \mathrm{g} /$ mouse) in Freund's complete adjuvant (FCA). Additional groups of uninfected mice received OVA plus FCA or FCA only. Mice were killed with $\mathrm{CO}_{2}$ gas and exsanguinated on days 7 or 14 post-OVA or FCA administration. Data from three replicate experiments were pooled. The numbers of mice per group are shown in Table 1. 


\section{Serology}

Mice were monitored for seroconversion as evidence of infection by indirect immunofluorescent staining using individual sera diluted $1: 10$ and a bivalent antigen consisting of MHV-JHM and MHV-S, as previously described [26]. For the measurement of OVAspecific antibody, 96-well plates (Costar Corp., Cambridge, MA) were coated overnight at $4^{\circ} \mathrm{C}$ with crystallized OVA (Sigma Chemical Co., St. Louis, MO; $250 \mu \mathrm{g} / \mathrm{ml}$ in $200 \mu \mathrm{l}$ of sodium carbonate buffer, $\mathrm{pH}$ 9.6). Negative control wells were coated with carbonate buffer. The wells were washed twice with phosphate buffered saline (PBS) containing $0.05 \%$ Tween20 (PBS-T) and treated for $1 \mathrm{~h}$ at $37^{\circ} \mathrm{C}$ with $3 \%$ gelatin in PBS. Following two additional washes with PBS-T, serum dilutions in PBS were added for $1 \mathrm{~h}$ at $37^{\circ} \mathrm{C}$. Horseradish peroxidase (HRP)-conjugated goat anti-mouse IgG 1 (Southern Biotechnology, Birmingham, AL) diluted 1:2000 in PBS-T or HRP-conjugated goat anti-mouse IgG2a (Southern Biotechnology) diluted $1: 500$ in PBS-T was added for $1 \mathrm{~h}$ at $37^{\circ} \mathrm{C}$ after two washes with PBS-T. After three further washes with PBS-T, 3,3',5,5'-tetramethylbenzidine (TMB; Kirkegaard and Perry Laboratories, Gaithersburg, MD) was added to the wells for $15 \mathrm{~min}$ followed by the addition of $1 \mathrm{~N} \mathrm{HCl} . \mathrm{A}_{450}$ were read on an automated plate reader (MR 600; Dynatech Laboratories, Alexandria, VA) and were considered significant if they exceeded by 3 S.D. the mean value for control wells treated with the same dilution of serum. Results are expressed as geometric mean titers [34] for sera with significant $A_{450}$ values at a dilution of 1:50 or greater. Selected sera from mice tested for IgG 2 a were eliminated from the analysis due to unacceptably high background readings.

\section{Virus detection and quantification}

Ten percent tissue homogenates were clarified by centrifugation, and the supernates were screened for infectivity by intracerebral inoculation of litters of two day old Sencar mice. Virus was quantified by inoculating serial $\log _{10}$ dilutions of tissue homogenates. Mortality during a one week period was recorded, and virus titers were calculated by the method of Reed and Muench [23].

\section{Reagents and mouse treatments}

Monoclonal antibody to mouse gamma IFN, designated XMG 1.2 [5], was precipitated with saturated ammonium sulfate and extensively dialyzed against $\mathrm{PBS}, \mathrm{pH} 7.2$. The final product contained $1 \times 10^{5}$ neutralizing units per ml of antibody when tested with 64 units of recombinant gamma IFN in the WEHI $279 \mathrm{~B}$ cell lymphoma bioassay [24]. Mice were given $2 \times 10^{4}$ neutralizing units daily by the intraperitoneal route, beginning one day prior to virus exposure through one day prior to necropsy. Recombinant mouse IFN- $\gamma$ (lot no. 5408 ; specific activity $\geqslant 1 \times 10^{7}$ units $/ \mathrm{mg}$; purity $>98 \%$ according to manufacturer) was obtained from Amgen Biologicals (Thousand Oaks, CA). Mice were given $2 \times 10^{4}$ units intraperitoneally and $2 \times 10^{3}$ units intranasally once daily on days $(-2)$ through $(+2)$ relative to virus exposure.

\section{Histology}

Liver and spleen were fixed in 10\% neutral buffered formalin, paraffin embedded, sectioned at $5 \mu \mathrm{m}$ and stained with hematoxylin and eosin.

\section{Statistical analysis}

Chi square analysis was used to test for differences in proportions, and Student's unpaired $t$ test was used to analyze differences in mean virus titers. 


\section{Results}

Sera from mice infected with MHV-JHM one day prior to OVA administration contained substantially elevated levels of antigen-specific $\operatorname{IgG} 2 \mathrm{a}$ on day 7 (Table 1) with geometric mean titers that were 17 times control (OVA only) values at that interval. There was a suggestion of a delayed $\operatorname{IgG} 2$ a response among mice infected with MHV-JHM three or five days after OVA administration, since sera from one of 24 mice tested on day 7 contained OVA-specific $\operatorname{IgG} 2 \mathrm{a}$, whereas four of eleven OVA-immunized, uninfected mice had seroconverted at that interval $\left(\chi^{2}=4.03 ; \mathrm{P}<5.0\right)$. Sera from higher proportions of mice in groups that received MHV-JHM on days $-4(83 \%),-1(88 \%)$ or 0 $(83 \%)$ relative to OVA contained OVA-specific IgG $2 \mathrm{a}$ on day 7 than the proportion that were OVA-immunized, but uninfected $(36 \%)$; however, these differences were not statistically significant. Mice infected four days prior to OVA administration had OVA-specific IgG 1 titers that were sevenfold lower than those of OVA-immunized, uninfected mice (Table 1), and the proportion of IgG 1-positive sera $(60 \%)$ was reduced compared to uninfected control sera $(92 \%)$.

Table 1. Ovalbumin (OVA)-specific IgG $2 \mathrm{a}$ and $\operatorname{IgG} 1$ titers in sera of BALB/cByJ mice infected at varying intervals with MHV-JHM

\begin{tabular}{|c|c|c|c|c|}
\hline \multirow{2}{*}{$\begin{array}{l}\text { Day of MHV-JHM } \\
\text { infection relative to } \\
\text { OVA administra- } \\
\text { tion }\end{array}$} & \multicolumn{2}{|l|}{ Day 7} & \multicolumn{2}{|l|}{ Day 14} \\
\hline & $\operatorname{IgG} 2 \mathrm{a}$ & $\operatorname{IgG} 1$ & $\operatorname{IgG} 2 \mathrm{a}$ & $\operatorname{IgG} 1$ \\
\hline OVA only & $\begin{array}{c}4 / 11 \\
350 \pm 171\end{array}$ & $\begin{array}{c}11 / 12 \\
3,488 \pm 204\end{array}$ & $\begin{array}{c}10 / 10 \\
1,600 \pm 252\end{array}$ & $\begin{array}{c}10 / 10 \\
112,640 \pm 11,072\end{array}$ \\
\hline-7 & $\begin{array}{c}7 / 15 \\
314 \pm 98\end{array}$ & $\begin{array}{c}13 / 15 \\
1,416 \pm 68\end{array}$ & $\begin{array}{c}8 / 8 \\
8,832 \pm 240\end{array}$ & $\begin{array}{c}8 / 8 \\
115,712 \pm 8,000\end{array}$ \\
\hline-4 & $\begin{array}{c}10 / 12 \\
480 \pm 230\end{array}$ & $\begin{array}{c}9 / 15 \\
488 \pm 82\end{array}$ & $\begin{array}{c}6 / 6 \\
11,712 \pm 117\end{array}$ & $\begin{array}{l}6 / 6 \\
68,096 \pm 5,248\end{array}$ \\
\hline-1 & $\begin{array}{c}7 / 8 \\
5,952 \pm 1,936\end{array}$ & $\begin{array}{c}11 / 14 \\
1,600 \pm 114\end{array}$ & $\begin{array}{c}7 / 7 \\
132,095 \pm 6,080\end{array}$ & $\begin{array}{l}8 / 8 \\
89,600 \pm 8,896\end{array}$ \\
\hline 0 & $\begin{array}{c}10 / 12 \\
800 \pm 156\end{array}$ & $\begin{array}{c}16 / 16 \\
1,600 \pm 100\end{array}$ & $\begin{array}{c}8 / 8 \\
14,464 \pm 189\end{array}$ & $\begin{array}{c}12 / 12 \\
55,296 \pm 3,264\end{array}$ \\
\hline+1 & $\begin{array}{c}4 / 13 \\
150 \pm 100\end{array}$ & $\begin{array}{c}15 / 17 \\
1,600 \pm 66\end{array}$ & $\begin{array}{c}8 / 9 \\
12,032 \pm 416\end{array}$ & $\begin{array}{l}8 / 8 \\
48,128 \pm 12,544\end{array}$ \\
\hline+3 & $0 / 12$ & $\begin{array}{c}16 / 17 \\
2,400 \pm 99\end{array}$ & $\begin{array}{c}5 / 5 \\
2,240 \pm 684\end{array}$ & $\begin{array}{c}5 / 5 \\
40,960 \pm 9,728\end{array}$ \\
\hline+5 & $\begin{array}{l}1 / 12 \\
1,600\end{array}$ & $\begin{array}{c}17 / 17 \\
5,280 \pm 75\end{array}$ & $\begin{array}{c}5 / 6 \\
1,120 \pm 260\end{array}$ & $\begin{array}{c}6 / 6 \\
59,904 \pm 7,488\end{array}$ \\
\hline
\end{tabular}

Results are shown as number positive at a dilution of $1: 50$ or greater/number tested, and geometric mean enzyme-linked immunosorbent assay titer \pm SD for positive sera 
Sera collected from mice at 14 days after OVA immunization yielded a more clear-cut pattern. IgG 2 a titers were elevated in sera from mice that received virus any time from seven days prior to OVA through one day after OVA (Table 1). As had been seen among mice bled seven days after administration of OVA, the most marked increase in OVA-specific IgG 2 a (83-fold increase over controls) occurred among mice infected one day prior to immunization. Sera from all infected mice except those exposed to virus seven days prior to immunization contained reduced levels of OVA-specific IgG 1 (Table 1). However, the greatest reduction (mice infected three days after OVA immunization) was three-fold. Mice infected seven days prior to immunization yielded IgG 1 titers equivalent to uninfected controls.

Isotype distribution of ovalbumin-specific antibody was also analyzed by determining IgG 1: IgG 2 a ratios for sera from mice bled on day 14 (Fig. 1). Although the two tests may have inherently different sensitivities, this parameter would be expected to remain relatively constant, since the two assays were always run in parallel, and the same reagents were used throughout the study. This analysis revealed that $\mathrm{IgG} 1$ levels in sera from uninfected, OVA-immunized mice were 70 -fold higher than IgG 2 a levels. In contrast, the ratio was less than one for sera from mice infected one day prior to immunization and measured on day 14 .

The elevated IgG 2 a OVA-specific response of most groups of MHV-infected mice and the preferential production of this isotype by mice infected one day prior to antigen administration suggested that these mice were producing IFN$\gamma$. However, using the WEHI 279 B cell lymphoma bioassay [24], attempts to detect the cytokine in sera of infected mice failed, as had earlier attempts to

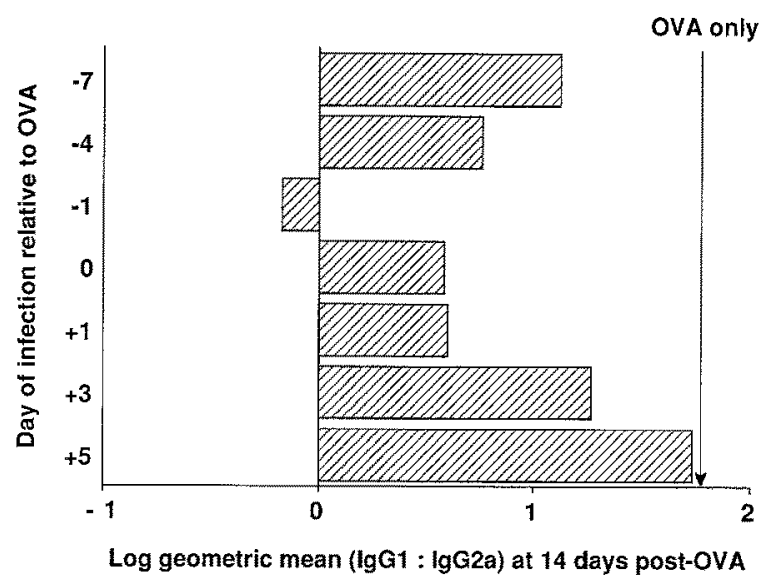

Fig. 1. $\log _{10}$ ratio of $\operatorname{IgG} 1: \operatorname{IgG} 2$ a geometric mean ovalbumin (OVA)-specific titers at 14 days after OVA immunization. Mice were infected with MHV-JHM at varying times (shown on ordinate) relative to OVA administration. Geometric mean titers were calculated for those sera that were enzyme-linked immunosorbent assay-positive at dilutions of $1: 50$ or greater 
detect IFN- $\gamma$ in supernates of concanavalin A-stimulated spleen cells from acutely infected mice $[10,27]$. It was reasoned that, if IFN $-\gamma$ was being produced below the level of assay detection and was responsible for the induction of an elevated $\mathrm{IgG} 2$ a response, treatment of OVA-immunized, MHV-infected mice with anti-IFN- $\gamma$ should restore, at least partially, the IgG 1 OVA-specific response. In two experiments, $94 \%$ of mice inoculated orally with MHV-JHM and treated with XMG1.2 died with survival times substantially shorter than those of mock-treated, infected mice ( $6.8 \pm 0.8$ days vs $9.3 \pm 3.4$ days). This suggested that IFN- $\gamma$ was produced during MHV infection and was influencing the course of disease.

In an attempt to delineate the role of IFN- $\gamma$ in the pathogenesis of MHVJHM infection, groups of athymic or euthymic BALB/c mice were treated with monoclonal anti-IFN- $\gamma$ (XMG 1.2) or were mock-treated with dialysis buffer (PBS) and exposed orally to virus. Athymic mice were included because they produce IFN- $\gamma$ by virtue of fully competent natural killer cells [19]. Four mice per genotype and treatment group were necropsied daily on post-infection days one through five. Liver and spleen sections from all mice were examined histologically, and virus in the same organs of mice necropsied on days four and five post-infection was quantified. On day 4 , mock-treated athymic and euthymic mice and XMG 1.2-treated euthymic mice had rare scattered foci of necrotizing hepatitis, with necrosis of hepatocytes and infiltration of neutrophilic leukocytes. XMG 1.2-treated athymic mice had hepatitis that was similar in quality to that of their mock-treated counterparts, but necrotic foci were more numerous. On day 5, differences between treatment groups were more striking. XMG1.2treated athymic mice had numerous large, coalescing foci of hepatocellular necrosis, with only modest leukocytic response (Fig. 2 A). In contrast, mocktreated athymic mice had fewer, smaller foci of hepatitis with less necrosis and infiltration with more leukocytes (Fig. 2B). XMG1.2-treated euthymic mice had more foci of hepatitis than either their mock-treated counterparts or mock treated athymic mice. Lesions among the latter three groups were qualitatively similar, with infiltration of both neutrophilic and mononuclear leukocytes. Microscopic differences between treatment groups were not seen in spleens of mice necropsied on day 4, but were evident on day 5. XMG 1.2-treated athymic mice, and to a lesser extent XMG 1.2-treated euthymic mice, had severe necrosis of the periarteriolar regions of the white pulp. Necrosis was present in the same regions of spleens from mock-treated mice, but was less severe.

Virus titers in livers and spleens of XMG1.2-treated mice necropsied on days 4 and 5 post-inoculation, whether athymic or euthymic, were higher than those in the corresponding tissues of mock-treated mice (Table 2). For athymic mice, these differences were statistically significant for both tissues on both days. Among euthymic mice, statistically significant differences in virus titers occurred in the spleen, but not the liver.

Since treatment of MHV-JHM-infected BALB/cByJ mice with antibody to IFN $-\gamma$ resulted in decreased survival time and increased virus titers in two target 

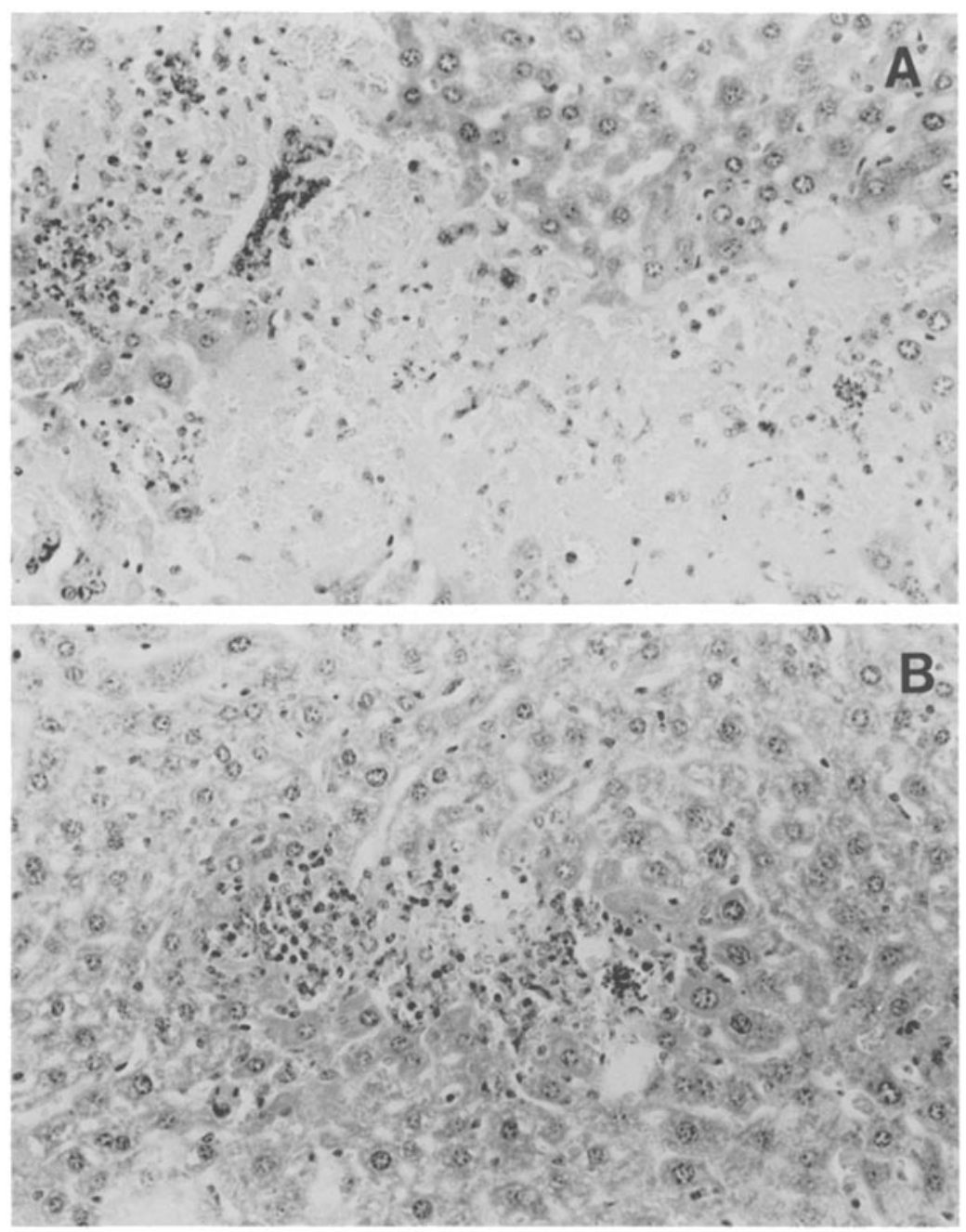

Fig. 2. A Liver of XMG 1.2-treated athymic mouse at 5 days after oral MHV-JHM inoculation. Large coalescing foci of necrosis have minimal leukocytic infiltration, as represented by this field. B Liver of PBS-treated athymic mouse at 5 days after oral MHV-JHM inoculation. Compared to livers of XMG 1.2-treated athymic mice (A), foci of hepatitis are less numerous and have less necrosis and more leukocytic infiltration, as represented by this field. $\times 135$

organs, the ability of IFN- $\gamma$ supplementation to ameliorate disease was assessed. Treatment of MHV-JHM-infected mice with recombinant IFN- $\gamma$ resulted in significantly reduced mortality (Table 3 ). Virus titers in liver, spleen and brain of IFN- $\gamma$ treated mice at five days post-inoculation were lower than those in the corresponding organs of mock-treated mice (Table 3), but only the differences in liver titers were statistically significant. 
Table 2. Mean MHV-JHM titers ( $\log _{10}$ icLD $D_{50}$ per gram \pm S.D.) in livers and spleens of orally inoculated athymic $(\mathrm{nu} / \mathrm{nu})$ or euthymic $(\mathrm{nu} /+)$ BALB/c mice after mock treatment or administration of monoclonal antibody to mouse gamma interferon (XMG1.2)

\begin{tabular}{|c|c|c|c|c|c|}
\hline \multirow{4}{*}{ Genotype } & \multirow{4}{*}{ Treatment } & \multicolumn{4}{|c|}{ Days post-inoculation } \\
\hline & & \multicolumn{2}{|l|}{4} & \multicolumn{2}{|l|}{5} \\
\hline & & \multicolumn{4}{|l|}{ Organ } \\
\hline & & Liver & Spleen & Liver & Spleen \\
\hline Athymic & $\begin{array}{l}\text { Mock } \\
\text { XMG } 1.2\end{array}$ & $\begin{array}{l}4.3 \pm 0.8 \\
6.4 \pm 0.5\end{array}$ & $\begin{array}{l}4.6 \pm 0.4 \\
6.5 \pm 0.4\end{array}$ & $\begin{array}{l}4.2 \pm 0.4 \\
5.9 \pm 1.2\end{array}$ & $\begin{array}{l}4.3 \pm 0.3 \\
5.8 \pm 0.9\end{array}$ \\
\hline$P$ value ${ }^{a}$ & & 0.005 & 0.001 & 0.025 & 0.01 \\
\hline Euthymic & $\begin{array}{l}\text { Mock } \\
\text { XMG } 1.2\end{array}$ & $\begin{array}{l}4.6 \pm 1.3 \\
4.7 \pm 0.0\end{array}$ & $\begin{array}{l}4.6 \pm 0.9 \\
5.9 \pm 0.4\end{array}$ & $\begin{array}{l}4.9 \pm 0.9 \\
6.0 \pm 1.0\end{array}$ & $\begin{array}{l}4.7 \pm 1.1 \\
6.5 \pm 0.4\end{array}$ \\
\hline$P$ value & & N.S. & 0.025 & N.S. & 0.01 \\
\hline
\end{tabular}

${ }^{a} P$ values are based on unpaired $t$ test performed on virus titers in organs of mocktreated vs. XMG 1.2-treated mice. N.S. Not significantly different

Table 3. Mean virus titers in target organs 5 days after intranasal inoculation of BALB/ cByJ mice with MHV-JHM and mock treatment or administration of recombinant gamma interferon and mortality rates in observation groups

\begin{tabular}{|c|c|c|c|c|}
\hline & \multicolumn{4}{|c|}{ No. positive / no. tested $\left(\log _{10}\right.$ icLD $D_{50}$ per $\operatorname{gram}^{\mathrm{a}} \pm$ S.D. $)$} \\
\hline & \multicolumn{3}{|l|}{ Organ } & \multirow[t]{2}{*}{ Mortality } \\
\hline & Liver & Spleen & Brain & \\
\hline Mock-treated & $8 / 8(7.0 \pm 0.3)$ & $9 / 9(5.7 \pm 0.3)$ & $7 / 8(6.3 \pm 0.5)$ & $12 / 12(100 \%)$ \\
\hline IFN- $\gamma$ treated & $9 / 9(5.4 \pm 0.9)$ & $6 / 8(5.2 \pm 0.3)$ & $7 / 9(4.8 \pm 1.7)$ & $7 / 12(58 \%)$ \\
\hline $\mathrm{P}$ value & $0.001^{b}$ & N.S. ${ }^{b}$ & N.S. ${ }^{b}$ & $<0.05^{\mathrm{c}}$ \\
\hline
\end{tabular}

${ }^{a}$ Mean virus titers for virus-positive organs

${ }^{\mathrm{b}} \mathrm{P}$ value is based on unpaired $t$ test performed on virus titers in organs of mock-treated vs. gamma interferon-treated mice. Differences in proportions of virus-positive organs were not statistically significant. N.S. Not significantly different

${ }^{\mathrm{c}} \mathrm{P}$ value based on $\chi^{2}$ analysis for differences in proportions $\left(\chi^{2}=4.04\right)$

\section{Discussion}

There have been a few reports detailing the responses of MHV-infected mice to nonreplicating antigens or other viruses. Mice infected intraperitoneally with MHV-3 two or four days prior to sheep red blood cell immunization yielded depressed IgM and IgG plaque-forming cell responses [33], whereas mice in- 
fected at the time of or one day after red cell administration yielded elevated plaque-forming cell responses. This could be correlated with the timing of IFN$\alpha / \beta$ responses relative to antigen administration. More recently, intranasal administration of MHV-A 59 one day prior to tetanus toxoid immunization resulted in elevated antigen-specific IgG with a four-fold decrease in the percent of $\operatorname{IgG}$ that was $\operatorname{IgG} 1$ and a like increase in the proportion that was $\operatorname{IgG} 2 \mathrm{a}$ [7]. Our results with MHV-JHM and a different immunizing antigen confirm and extend that finding by showing elevated $\operatorname{IgG} 2 \mathrm{a}$ OVA-specific responses over a wide range of infection intervals. Timing is crucial, however, to the extent that $\operatorname{IgG} 2$ a titers exceeded $\operatorname{IgG} 1$ titers only among mice infected one day prior to antigen administration.

MHV infection reportedly increases resistance to a variety of secondary viral infections. Pre-infection of mice with MHV increased resistance to lethal Sendai virus infection in a normally susceptible genotype and interfered with replication of pneumonia virus of mice in respiratory tract tissues [4]. Subclinical MHV infection delayed increased plasma lactic dehydrogenase (LDH) levels resulting from LDH-elevating virus [11]. Natural, inapparent MHV infection also increased resistance to encephalomyocarditis virus and reduced the protective effect of exogenous IFN- $\alpha$ or $-\beta$ [9]. Since MHV infection induces IFN- $\alpha / \beta$ production $[15,25,33]$, it was postulated that increased resistance to these secondary infections was due to endogenous IFN $-\alpha / \beta$ levels and that the effects of exogenous IFN were masked by the endogenous production [9].

There are now a limited number of reports showing that IFN- $\gamma$ modulates the pathogenesis of virus infections. Treatment of mice with a different rat antimouse IFN- $\gamma$ monoclonal antibody or with a sheep-derived antibody against recombinant IFN $-\gamma$ resulted in reduced clearance or enhanced replication of lymphocytic choriomeningitis virus (LCMV) in mice $[17,19]$. Neutralization of IFN- $\gamma$ in LCMV-infected athymic C57BL/6 resulted in enhanced virus replication [19] as seen in the studies reported here. More recently, a rat antimouse IFN- $\gamma$ monoclonal antibody prevented IL 2-induced recovery of athymic mice infected with recombinant vaccinia virus encoding murine IL 2 [16], suggesting that IL 2-induced IFN- $\gamma$ production was responsible for rapid clearance of this construct. Virus replication and associated mortality were unaffected among anti-IFN- $\gamma$-treated athymic mice infected with a control virus construct encoding HSV TK and A/PR/8/34 HA [16]. However, administration of recombinant IFN- $\gamma$ to mice infected with the control construct significantly increased their survival time, although all treated mice eventually died of disseminated infection [16]. Resistance of intraperitoneally inoculated $\mathrm{A} / \mathrm{J}$ mice to MHV-3 also correlates with the ability of this genotype to produce IFN- $\gamma$ after infection [21]. The accumulated data strongly suggest that IFN- $\gamma$, whether induced during the course of infection or administered therapeutically, limits viral replication in vivo. In the case of vaccinia virus encoding IL 2, IFN- $\gamma$ apparently mediates recovery of athymic mice.

Our data with mice exposed by presumed natural routes to MHV-JHM 
show that endogenous IFN- $\gamma$ modulates the pathogenesis of infection in both athymic and euthymic mice. In earlier studies with LCMV [13] and the current experiments with MHV, IFN- $\gamma$ was either present in very low concentration or undetected in sera of infected mice, despite the fact that anti-IFN- $\gamma$ treatment resulted in elevated virus titers. These observations may stem from insensitivity of the assays used to detect IFN- $\gamma$. The vesicular stomatitis virus cytopathic effect reduction assay was used in the LCMV studies, and the WEHI 279 cell bioassay was used in the current experiments. The WEHI 279 cell bioassay is as sensitive as the Ia induction assay for detection of IFN- $\gamma$ [24], but sensitivity comparisons with other methods have not been reported. Use of the sandwich enzyme-linked immunosorbent assay, as reported by Karupiah and co-workers [16], would likely reveal the presence of IFN- $\gamma$ in sera or tissue homogenates from infected mice.

Based on both histologic evaluation and virus quantification, the effect of administration of anti-IFN- $\gamma$ antibody was more marked in athymic than in euthymic mice. This may be due to higher endogenous concentrations of IFN$\gamma$ in euthymic mice by virtue of functional $T$ cells as well as natural killer cells. Neither natural killer cells nor endogenous levels of IFN- $\gamma$ are sufficient to afford protection, however, since athymic mice do die after natural or experimental infection with MHV [14, 32]. MHV-JHM also kills virtually all BALB/ $c$ mice exposed by the intranasal route. The lethal effect of infection could be partially overcome by administration of recombinant IFN- $\gamma$, with a concomitant and significant decrease in virus concentration in the liver.

Others have postulated that virus infections preferentially activate the IFN$\gamma$ producing $\mathrm{T}_{\mathrm{h}} 1$ subset of $\mathrm{CD}^{+}{ }^{+} \mathrm{T}$ cells [7], based on the fact that most infections result in enhanced $\operatorname{IgG} 2$ a production. Using LDH-elevating virus or the FL strain of mouse adenovirus, attempts were made to inhibit virusassociated IgG 2 a production by injection of several different IFN- $\gamma$-specific monoclonal antibodies [6]. These efforts failed, although it was not clear whether treatment simply did not affect isotype distribution or whether the mice succumbed to infection. In the current study, neutralization of IFN- $\gamma$ in vivo resulted in high mortality with reduced survival times, thereby inhibiting our efforts to show a direct link between virus-induced IFN- $\gamma$ production and enhanced $\operatorname{IgG} 2$ a responses. Among mouse strains susceptible to MHV after exposure by natural routes, lesions and mortality occur at or near the infectious dose level, and the severity of lesions is independent of virus dose $[1,2]$. In the case of MHV-JHM inoculation of the BALB/c mouse by presumed natural routes, the median infectious and lethal doses are essentially identical (unpubl. data). Therefore, subsequent studies designed to reveal whether neutralization of IFN- $\gamma$ reverses preferential IgG 2 a production will require the use of mouse genotypes more resistant to the lethal effects of MHV-JHM infection [29] or of a less virulent MHV strain. Our studies with MHV-JHM in the BALB/c mouse have shown, however, that endogenous IFN- $\gamma$ modulates coronavirusassociated mortality, virus replication and tissue damage in a susceptible host. 
IFN- $\gamma$ supplementation also ameliorated the disease process, as evidenced by reduced mortality and significantly lower liver virus titers.

\section{Acknowledgements}

This research was supported by NIH grants RR04507 and RR02039. The authors thank Deborah F. Winograd, Deborah S. Beck, and Jane Dunn for excellent technical assistance.

\section{References}

1. Barthold SW, Beck DS, Smith AL (1986) Mouse hepatitis virus nasoencephalopathy is dependent upon virus strain and host genotype. Arch Virol 91: 247-256

2. Barthold SW, Smith AL (1987) Response of genetically susceptible and resistant mice to intranasal inoculation with mouse hepatitis virus JHM. Virus Res 7: 225-239

3. Beck L, Spiegelberg HL (1989) The polyclonal and antigen-specific IgE and IgG subclass response of mice injected with ovalbumin in alum or complete Freund's adjuvant. Cell Immunol 123: 1-8

4. Carrano VA, Barthold SW, Beck DS, Smith AL (1984) Alteration of viral respiratory infections of mice by prior infection with mouse hepatitis virus. Lab Anim Sci 34: 573576

5. Cherwinski HM, Schumacher JH, Brown KD, Mosmann TR (1987) Two types of mouse helper T cell clone. III. Further differences in lymphokine synthesis between Th 1 and Th 2 clones revealed by RNA hybridization, functionally monospecific bioassays, and monoclonal antibodies. J Exp Med 166: 1229-1244

6. Coutelier J-P, Coulie PG, Wauters P, Heremans H, van der Logt JTM (1990) In vivo polyclonal B-lymphocyte activation elicited by murine viruses. J Virol 64: 5383-5388

7. Coutelier J-P, van der Logt JTM, Heessen FWA, Vink A, van Snick J (1988) Virally induced modulation of murine IgG antibody subclasses. J Exp Med 168: 2373-2378

8. Coutelier J-P, van der Logt JTM, Heessen FWA, Warnier G, van Snick J (1987) IgG 2 a restriction of murine antibodies elicited by viral infections. J Exp Med 165: 64-69

9. Dempsey WL, Smith AL, Morahan PS (1986) Effect of inapparent murine hepatitis virus infections on macrophages and host resistance. J Leuk Biol 39: 559-565

10. de Souza MS, Smith AL, Bottomly K (1991) Infection of BALB/cByJ mice with the JHM strain of mouse hepatitis virus alters in vitro splenic Tcell proliferation and cytokine production. Lab Anim Sci 41: 99-105

11. Dillberger JE, Monroy P, Altman NH (1987) Delayed increase in plasma lactic dehydrogenase activity in mouse hepatitis virus-infected mice subsequently infected with lactic dehydrogenase virus. Lab Anim Sci 37: 792-794

12. Finkelman FD, Katona IM, Mosmann TR, Coffman RL (1988) IFN-gamma regulates the isotypes of Ig secreted during in vivo humoral immune responses. J Immunol 140: $1022-1027$

13. Frei K, Leist TP, Meager A, Gallo P, Leppert D, Zinkernagel RM, Fontana A (1988) Production of B cell stimulatory factor- 2 and interferon gamma in the central nervous system during viral meningitis and encephalitis. J Exp Med 168: 449-453

14. Fujiwara K (1988) Persistent mouse hepatitis virus infection in nude mice. Japan J Exp Med 58: 115-121

15. Garlinghouse LE, Smith AL (1985) Responses of mice susceptible or resistant to lethal infection with mouse hepatitis virus, strain JHM, after exposure by a natural route. Lab Anim Sci 35: 469-472

16. Karupiah G, Blanden RV, Ramshaw IA (1990) Interferon gamma is involved in the recovery of athymic nude mice from recombinant vaccinia virus/interleukin 2 infection. J Exp Med 172: 1495-1503 
100 Abigail L. Smith et al.: Gamma interferon in murine coronavirus infection

17. Klavinskis LS, Gleckler R, Oldstone MBA (1989) Cytotoxic T lymphocyte control of acute lymphocytic choriomeningitis virus infection: interferon gamma, but not tumour necrosis factor alpha, displays antiviral activity in vivo. J Gen Virol 70: 3317-3325

18. Kraft V, Meyer B (1986) Diagnosis of murine infections in relation to test methods employed. Lab Anim Sci 36: 271-276

19. Leist TP, Eppler M, Zinkernagel RM (1989) Enhanced virus replication and inhibition of lymphocytic choriomeningitis virus disease in anti-gamma interferon-treated mice. J Virol 63: 2813-2819

20. Lindsey JR (1986) Prevalence of viral and mycoplasmal infections in laboratory rodents. In: Bhatt PN, Jacoby RO, Morse HC, New A (ed) Viral and mycoplasmal infections of laboratory rodents. Effects on biomedical research. Academic Press, New York, pp 801-808

21. Lucchiari MA, Pereira CA (1989) A major role of macrophage activation by interferongamma during mouse hepatitis virus type 3 infection. I. Genetically dependent resistance. Immunobiology 180: 12-22

22. Lussier G, Descoteaux J-P (1986) Prevalence of natural virus infections in laboratory mice and rats used in Canada. Lab Anim Sci 36: 145-148

23. Reed LJ, Muench $H$ (1938) A simple method of estimating fifty percent endpoints. Am J Hyg 27: 493-497

24. Reynolds DS, Boom WH, Abbas AK (1987) Inhibition of B lymphocyte activation by interferon gamma. J Immunol 139: 767-773

25. Schindler L, Engler H, Kirchner H (1982) Activation of natural killer cells and induction of interferon after injection of mouse hepatitis virus type 3 in mice. Infect Immun 35: 869-873

26. Smith AL (1983) An immunofluorescence test for detection of serum antibody to rodent coronaviruses. Lab Anim Sci 33: 157-160

27. Smith AL, Bottomly K, Winograd DF (1987) Altered splenic T cell function of BALB/ cByJ mice infected with mouse hepatitis virus or Sendai virus. J Immunol 138: 34263430

28. Smith AL, Casals J, Main AJ (1983) Antigenic characterization of Tettnang virus: complications caused by passage of the virus in mice from a colony enzootically infected with mouse hepatitis virus. Am J Trop Med Hyg 32: 1172-1176

29. Smith AL, Winograd DF, de Souza MS (1991) In vitro splenic T cell responses of diverse mouse genotypes after oronasal exposure to mouse hepatitis virus, strain JHM. Lab Anim Sci 41: 106-111

30. Snapper CM, Paul WE (1987) Interferon-gamma and B cell stimulatory factor-1 reciprocally regulate Ig isotype production. Science 236: 944-947

31. Snapper CM, Peschel C, Paul WE (1988) IFN-gamma stimulates IgG 2 a secretion by murine B cells stimulated with bacterial lipopolysaccharide. J Immunol 140: 2121-2127

32. Tamura T, Taguchi G, Ueda K, Fujiwara K (1977) Persistent infection with mouse hepatitis virus of low virulence in nude mice. Microbiol Immunol 21: 683-691

33. Virelizier J-L, Virelizier AM, Allison AC (1976) The role of circulating interferon in the modifications of immune responsiveness by mouse hepatitis virus (MHV-3). J Immunol 117: 748-753

34. White C (1973) Statistical methods in serum surveys. In: Paul JR, White C (ed) Serological epidemiology. Academic Press, New York, pp 19-23

Authors' address: Dr. Abigail L. Smith, Section of Comparative Medicine, Yale University School of Medicine, 333 Cedar Street, P.O. Box 3333, New Haven, CT 06510, U.S.A.

Received January 26, 1991 